\title{
Antecedents and Innovation Performance Implications of MNC Political Ties in the Chinese Automotive Supply Chain
}

\author{
Ruey-Jer 'Bryan' Jean ${ }^{1}$ (D) Rudolf R. Sinkovics ${ }^{2,3,4}$ (D) . Stefan Zagelmeyer ${ }^{2}$ (D)
}

Received: 6 November 2016 / Revised: 9 October 2018 / Accepted: 22 October 2018 /

Published online: 28 November 2018

(c) The Author(s) 2018

\begin{abstract}
The development of political ties represents a non-market strategy, which may substitute for formal contracts in safeguarding against transaction risks of innovation processes in emerging markets with weak institutions, such as China. Previous work has largely ignored the role political ties play in product innovation, and especially with respect to subsidiaries of foreign multinational corporations (MNCs). This study investigates the antecedents and role of political ties in relation to the innovation performance of foreign subsidiaries supplying automotive parts in China. Our analysis is based on survey data from 170 foreign MNC supplier firms in China. A partial least squares structural equation modelling (PLS-SEM) approach is employed to examine relationships through a 'soft-modelling' analysis, using SmartPLS 3. The results empirically confirm the positive impact of political ties, in terms of enhancing foreign MNCs' product innovation performance in China. Furthermore, it is found that the extent to which foreign suppliers invest in and maintain political ties is driven by a mix of organizational and environmental factors, namely protection orientation, relationship-specific investment, technological dynamism and competitor opportunism. The paper contributes to the understanding of the antecedents and the implications of political ties with respect to the innovation performance of foreign MNC subsidiaries in emerging economies.
\end{abstract}

Keywords Product innovation · Political ties · Institutional environment · Emerging market $\cdot$ MNCs

Rudolf R. Sinkovics

Rudolf.Sinkovics@manchester.ac.uk

1 National Chengchi University, Taipei, Taiwan

2 Alliance Manchester Business School, The University of Manchester, Manchester, UK

3 Lappeenranta University of Technology, Lappeenranta, Finland

4 Department of Strategic Management, Fox School of Business, Temple University, Philadelphia, PA, USA 


\section{Introduction}

Economic reforms, the opening up of the economy to foreign direct investment and substantial growth over the past decades have made China an attractive destination for multinational corporations (MNCs). In line with its 5-year plan to move the country from 'Made in China' to 'Created in China' (Zhou et al. 2017), the Chinese government has welcomed the activities of MNCs, especially with respect to technology transfer and the technological upgrading of domestic firms, as an essential ingredient of its development, innovation and growth strategy (Gu et al. 2016; Hu 2017; OECD 2007).

For a foreign MNC, doing business in China may prove challenging due to the specific characteristics of the Chinese business system (Redding and Witt 2009; Witt 2010), which involves specific roles and behaviour on the part of local partners and competitors, the government and the broader institutional setting. Zhang and Zhang (2014) argue that the socialist market-economy system in China requires companies not only to engage in market-related strategies in order to be successful, but also to pursue political strategies and thus to establish and maintain political ties to the Communist-Party-led government authorities (Lawton and Rajwani 2015; Wang et al. 2017; Zhang, Zhao et al. 2016b).

The recent literature has increasingly picked up on the topic of corporate political activities as part of a non-market strategy (Mellahi et al. 2016; Sojli and Tham 2017). Extant research on the antecedents and outcomes of corporate political strategies and political ties in China has mostly focused on economic and operational performance measures (Arnoldi and Villadsen 2015; Luo et al. 2015; Sheng et al. 2011; Zhang and Zhang 2014). While some research shows that political ties can enhance firms' performance ( $\mathrm{Li}$ and Zhang 2007), the empirical analysis by Ridge et al. (2017) shows that there may be positive but diminishing returns related to lobbying breadth. Other researchers argue that political ties can generate some negative effects due to over-embeddedness and a lock-in effect (Sun et al. 2012). A metaanalysis by Luo et al. (2015) of the existing empirical research on the link between political ties and performance shows that the benefits for firms depend on the characteristics of the political ties, i.e. the relevant level of government support, and are thus closely linked to the specific form of political economy of China.

In recent years, research has moved towards analysing the impact of political ties on corporate-level innovation performance, establishing a link between political ties and innovation ambidexterity (Zhang and Cui 2017), emphasizing the role of political networks for absorptive capacity (Kotabe et al. 2017) and highlighting the relevance of political ties to the local Communist Party committees for innovation performance (Zhang, Liang et al. 2016a). However, research on the link between the political ties and corporate innovation performance, including product innovation, of foreign-owned firms in China is largely missing. This neglect is especially surprising considering that the role of foreign subsidiaries in China has gradually shifted from a focus on manufacturing to an increasing engagement in innovation activities (Zhou et al. 2017). The China Innovation Survey 2014, conducted by the Benelux Chamber of Commerce in China, shows that more than 
two-thirds of the foreign MNCs there are engaged in innovation activities and are conducting research and development $(\mathrm{R} \& \mathrm{D})$ for their global markets (Veldhoen et al. 2014).

Many of the MNC subsidiaries engaging in innovation activities face significant challenges due to China's 'weak' or 'underdeveloped' institutional system (Hitt and $\mathrm{Xu}$ 2016) with respect to knowledge management and intellectual property protection (Brander et al. 2017; Wang 2016). Sheng et al. (2011) claim that firms can leverage their political connections and ties with different levels of government to acquire political legitimacy and resources, which, in turn, help enforce business contracts or stop unlawful competition, and protect their knowledge and intangible resources. The China Innovation Survey also shows that a major strategy for MNCs in managing their innovation processes in China is to develop government relationships (Veldhoen et al. 2014).

Against this background, we investigate the antecedents of political ties of MNCs and how these foster or hinder product innovation. Empirically, the study is situated within foreign automotive-supply MNCs in China. Our analysis draws on semi-structured in-depth interviews with 15 senior product and project managers or directors of supplier MNC subsidiaries, which feeds into questionnaire and survey data from 170 supplier MNCs collected in 2010. Foreign MNC subsidiaries supplying automotive parts in China offer an excellent setting for this study for the following reasons:

1. China is one of the world's fastest-growing automotive markets. MNC automotive makers, including vehicle assemblers and component suppliers, have been striving to enter the Chinese markets. For example, General Motors (GM), Ford, Toyota and Volkswagen (VW), have all established joint ventures with Chinese original equipment manufacturers (OEMs). In order to earn permission to enter China, MNCs must commit to bringing in modern product and process technologies, and help to develop the indigenous R\&D capabilities of their Chinese OEMs in their local operations. Performing this type of task requires a large amount of supplier involvement with the Chinese OEMs, in functions such as design, manufacturing, prototyping and testing.

2. For MNCs, the emerging market environment involves new firms and institutions based in complex and dynamic settings. New product development is a critical and particularly challenging task for these MNCs, essential to achieving greater local responsiveness to their host countries' markets. Multinational subsidiaries and joint ventures in the Chinese automotive industry have tried to adapt existing product designs to local conditions, regulations and consumer tastes. Accordingly, the unique empirical setting of this study provides a good opportunity to investigate the product innovation process under a volatile institutional environment.

3. The business culture in China emphasizes guanxi, the phenomenon of "cultivating intricate and pervasive personal ties" (Peng and Luo 2000, p. 487), which governs attitudes towards social and business relationships and plays a critical role in business operations in China (Barnes et al. 2011). Foreign MNCs have tried to develop governmental relationships to enhance their legitimacy and gain 
the resources necessary for doing business in China. Hence, this context provides a great opportunity for investigating the role of political ties in MNCs' success in emerging markets.

We expect to make the following contributions: First, we develop an integrated analytical framework, which zooms in on the importance for MNCs to develop political ties in China, while at the same time balancing the dual requirements of protecting their products/innovations from imitation and making relationship specific investments. Second, we link political ties with product innovation, an important but under-researched area (Kotabe et al. 2017). Third, we offer empirical evidence regarding external environmental factors, competition-related and technological, that dynamically interact with the aforementioned dimensions in China.

\section{Conceptual Framework and Hypotheses}

Political ties are defined as firms' informal social connections with government officials at various levels, including central and local government, and officials in regulatory agencies, such as tax or stock market administrative bureaus ( $\mathrm{Li}$ and Zhang 2007; Sheng et al. 2011). Political ties are types of social networks, which rely on personal interaction instead of formal contracts or markets for the acquisition of information and promotion of cooperation between firms and government.

The research model in this study (as shown in Fig. 1) introduces antecedents of political ties and product innovation as consequences thereof. The model is underpinned by the institutional perspective (Peng et al. 2008). In line with the institutional perspective, establishing and maintaining strong political ties can help the

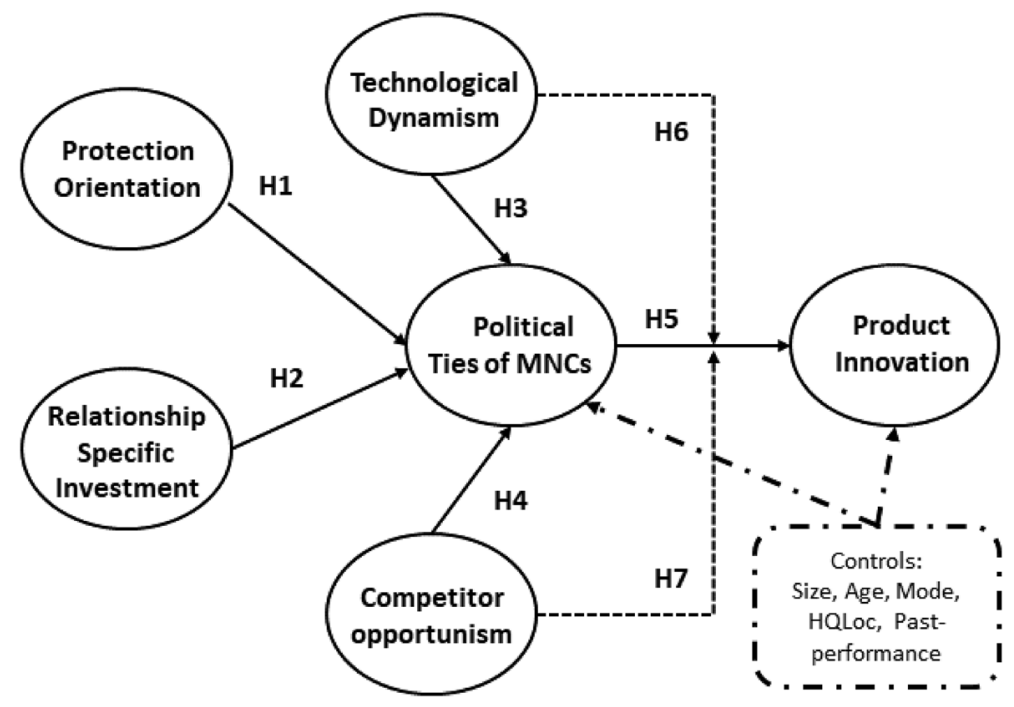

Fig. 1 Research model 
firm to obtain legitimacy and government support in a weak institutional environment. Political ties serve the function of a relational governance mechanism, which minimizes opportunistic behaviour by external actors in relation to product innovation. In line with resource-based theory, which argues that the firm's competitive advantage is a function of its resources and capabilities, political ties can provide the firm with the non-market capability of gaining access to necessary information and resources (Zhou and Li 2010).

The research model includes organizational and environmental factors. As far as the antecedents of political ties are concerned, we conceptualize protection orientation as a strategic-choice-related internal factor and relationship-specific investment as a relational factor. With respect to environmental factors, we draw on the literature on environmental uncertainty (Duncan 1972; Miller 1993; Werner et al. 1996) and distinguish and include (1) factors related the technological environment, i.e. technological dynamism, and (2) factors related to competitors, who behave opportunistically and thus modify the market outcomes to their advantage, in the analysis. Both competitor opportunism and technological dynamism also affect the link between political ties and product innovation, as moderator variables. In addition, we include several control variables in the model, namely firm size, years of operation in China and mode of operation (joint venture vs. wholly owned subsidiary), country of origin and past performance. Many of these variables have been explored and analysed in extant research, but they have not been studied simultaneously.

The following sections will introduce the concepts and constructs and discuss the arguments that support interrelationships between the constructs in the model.

\subsection{Political Ties}

Political ties result from activities aimed at engaging with government. For the Chinese business system, Zhang and Lin (2014) identify five different strategies that private enterprises use to influence government, political participation, information communication, political connection, "red hat" and material incentives (Zhang and Lin 2014, p. 59): "Political strategies include the political participation of managers in Chinese political institutions such as the People's Congress, the Chinese People's Political Consultative Conference or the Chinese Communist Party." The information strategy involves information exchange between company and government, specifically in terms of information about the company, and the provision of relevant information in exchange for government support. The political connection strategy consists of engaging with government officials and catering for their needs and preferences to establish a dependence relationship and advance the company's interests. The strategy of 'the red hat' involves cooperating with the state-owned enterprises of various government departments, in terms of ownership, or co-investment through payment of administrative fees. The last strategy, material incentives, involves providing the government or government officials with financial support.

Political ties have generally been regarded as non-market strategies which help firms acquire useful resources and ensure legitimacy when the market or institutional systems is weak or inefficient (Mellahi et al. 2016). This is particularly the case for 
China because the government still controls a significant portion of the resources and information, and has the power to approve certain projects. Kotabe et al. (2017) emphasize that governments in emerging economies are involved in resource allocation and thus the facilitation of business activities, for example through tax policies that determine financing. Political networking capabilities, i.e. the ability to use political ties, may provide access to relevant actors and policies, and industry-level information that allows companies to identify future business opportunities, but can also be used for traditional lobbying purposes.

Against the background of weak protection of intellectual property rights (IPR), political ties can be used to obtain government support, which may be especially useful for the enforcement of business contracts and opportunistic imitations by state-owned buyers (Kotabe et al. 2017). Taking an institutional perspective, Wu (2011) argues that, in political economies with weak market institutions, companies compensate through external connections, which may include political ties with the government, in order to do business. These ties act as substitutes for the effective rule of law and a reliable government that might otherwise provide a stable framework supporting business activities and transactions in the market (Peng and Luo 2000).

While the previous line of reasoning emphasizes positive effects in terms of an improvement in environmental fit, Wu (2011) claims that, on the other hand, political ties could interfere with the efficiency of organizational routines, through political interference and managerial disincentives. Kotabe et al. (2017) also emphasize that corporate lobbying, influence and thus rent-seeking activities may divert the company's attention away from engaging actively in innovation activities, through involvement in inefficient deal making with government agents.

Considering that China's institutional environment sports strong government support for innovation activities as part of China's development process, companies are faced with an environment in which their own innovation performance is likely to be affected "by the internal organisational capability, [...], as well as their political networking capability" (Kotabe et al. 2017, p. 1132).

\subsection{Drivers of Political Ties}

Existing work on the drivers of political ties has focused on external factors such as environmental uncertainty and internal factors such as the firm's strategic orientation, including its market, technological and entrepreneurial orientation ( $\mathrm{Li} 2005$ ). The following paragraphs introduce the antecedents of political ties that we included in our research model.

\subsubsection{Protection Orientation}

Protection orientation is defined as the extent to which firms' organizational culture and processes emphasize the importance of knowledge protection (Rivera-Santos et al. 2012). While learning orientation has received a reasonable amount of attention in the organizational learning literature (Hotho et al. 2015; Kale et al. 2000), 
contextual factors such as protection intent and orientation have so far been ignored. We argue that protection orientation is a strategic orientation dimension, which is relevant to knowledge management in emerging markets such as China, as there is insufficient intellectual property protection in the legal environment.

Protection orientation is related to MNCs' investment in political ties for the following reasons: MNCs with greater protection orientation highlight the importance of knowledge protection in their organizational culture and tend to engage with different internal and external stakeholders to reduce competitor opportunism and knowledge leakage. Political ties play a critical role in safeguarding against opportunistic behaviours in emerging markets (Sheng et al. 2011). Previous work also shows that relational capital can help to enhance a firm's knowledge protection capability (Kale et al. 2000). Hence, protection orientation motivates MNCs to engage with government officials to gain support and resources to reduce knowledge leakage and opportunism in the knowledge management process. During the field interviews for this research project, it emerged that protection-oriented MNCs tend to spend much time and resources dealing with political institutions to reduce knowledge leakage when working with Chinese automotive customers. Companies that are concerned and careful about the protection of knowledge and intellectual property, and that devise internal protection-related policies, practices and training for employees, are less likely to be affected by opportunistic behaviour. These companies reduce opportunities for others to gain advantages through opportunistic behaviour. Hence,

H1: Protection orientation positively affects political ties.

\subsubsection{Relationship-specific Investment}

Relationship-specific investment refers to the extent to which firms invest in particular business relationships in terms of physical and intangible assets-investments that cannot easily be recovered when the relationship is terminated (Williamson 1996). In the context of the automotive industry in China, this may involve relationship-specific investments made by supplier MNC subsidiaries, such as, for example, in machines, tools, or administrative processes that are specific to their relationships with their Chinese OEM buyers. During our field interviews, the manager of a German automotive lighting supplier reported having invested greatly in their information and tooling systems for SAIC motors in Shanghai.

According to transaction-cost economics, a firm's relationship-specific investment may be subject to the risk of opportunistic behaviour and exploitation by exchange partners that have not made a reciprocal commitment and investment (Rindfleisch and Heide 1997; Williamson 1979). Firms may also suffer from patent and copyright violations and breaches of contracts or other agreements or have to deal with deliberately deceptive strategies (Wanasika and Adler 2011; Zhou and Poppo 2010) of their partners, which may also work with other domestic or international firms, thus may have the dual role of exchange-partner and competitor. A firm can deploy certain safeguarding mechanisms to mitigate such transactional risk via 
mechanisms such as formal contracts, centralized control, mutual commitments and relational governance (Rindfleisch and Heide 1997; Zhou and Dean 2012).

Relational governance refers to the firm's use of informal relationships such as trust, flexibility and continuity to govern its exchange relationships. Previous work has suggested that political ties can serve as a relational governance approach (Sheng et al. 2011). Relationship (or political) ties with different government officials at different levels may help firms gain institutional support and resources, which then help mitigate the dysfunctional effects of competitor opportunism from exchange partners and competitors. For example, during our preliminary interviews with automotive MNCs, it emerged that suppliers had tried to develop lobbying strategies with the local government to gain support in dealing with competitor opportunism such as the infringement of IPR, stemming from their exchange relationships with customers and suppliers in China. Previous research also shows that relationshipspecific investment can motivate a firm's deployment of a relational governance strategy (Zaheer and Venkatraman 1995). Hence, we predict,

H2: Relationship-specific investment positively affects political ties.

\subsubsection{Technological Dynamism}

Technological dynamism is a critical dimension that captures specific aspects of environmental dynamism and uncertainty in the automotive industry in China. Technological advancements in this sector, such as electric cars and automated driving systems, are progressing rapidly and creating great technological dynamism for automotive suppliers. During our preliminary interviews with automotive supplier MNCs, one general manager stated, "The uncertainty of technology makes IPR issues become critical when we are working with our Chinese customers." Arguing in line with transaction-cost economics, environmental uncertainty causes adaptability issues and firms need to employ certain governance mechanisms to mitigate the transactional risks (Williamson 1996). Rindfleisch and Heide (1997) argue that technological dynamism motivates firms to adopt relational governance strategies, such as establishing and maintaining political ties, in exchange relationships to reduce opportunistic behaviours. Hence, we predict,

H3: Technological dynamism positively affects political ties.

\subsubsection{Competitor Opportunism}

The institutional perspective suggests that the institutional environment may shape the effects of a firm's strategic choices and their performance implications (Peng et al. 2008). Firms can use their political connections to increase their legitimacy and status, in turn helping them to enforce business contracts and guard against opportunistic exploitation by competitors (Sheng et al. 2011). Emphasizing capabilities, Zhang et al. (2017) argue that competitor opportunism, i.e. opportunistic and/ or illegal behaviour by competitors, represents a potential driver for the seeking of support in the institutional environment, e.g. in the form of political ties, to improve firms' capabilities to secure returns on their investment in innovation. We argue that 
this perception (based on past experience) of a risk of opportunistic exploitation may lead firms to invest in political ties as 'insurance' against opportunistic exploitation. Hence,

\section{H4: Competitor opportunism positively affects political ties.}

\subsection{Product Innovation}

Product innovation refers to the rate with which new products are generated and existing ones improved (Eisenhardt and Tabrizi 1995; Wang et al. 2008). Our study focuses primarily on incremental product innovation, in terms of the adaptation and improvement of current products and components, in response to a changing environment. While emerging market innovation literature broadly suggests that reverseinnovation is on the rise (Govindarajan and Ramamurti 2011), within the automotive sector core R\&D is still closely protected within home firm structures (Maxton and Wormald 2014) and innovation activities of foreign MNC subsidiaries in emerging markets predominantly involve tasks such as adapting general designs to the local environment (Zhao and Anand 2009). This could range from fitting a new engine to redesigning the exterior and interior of a vehicle. This is illustrated by Zhao et al. (2005), who report that GM-Shanghai made 600 engineering changes to tailor the Buick Century to Chinese driving conditions and regulations.

In our research model we argue for a direct link between political ties and product innovation. In line with transaction-cost economics, firms manage and safeguard against transactional hazards in exchange relationships by employing different interorganizational governance mechanisms, including formal and informal approaches. The knowledge-based view claims that knowledge crucial for the competitive advantage of a firm often resides outside of it. This encourages firms to acquire or create new knowledge through external collaborations with different partners (Grant and Baden-Fuller 2004).

Extant research has suggested that a firm's ties with external parties such as alliances and intermediaries enhance its product innovation performance (Zhang and $\mathrm{Li}$ 2010). With respect to the link between political ties and innovation performance, research confirms an interaction between the benefits of improved environmental fit on the one hand and reduced efficiency stemming from political intervention and managerial disincentives on the other (Wu 2011). Zhang, Zhao et al. (2016b) and Nan et al. (2016) find that local political ties based on local party committees in Chinese firms, which act as both departments of the firms and grassroots-level organizations of the Chinese Communist Party, do affect the firms' incremental and radical innovations in a positive way. Xin et al. (2016) find that political ties do not have a significantly positive impact on exploratory innovation at the pre-development stage, but do moderate the relationship between exploratory innovation and firm performance at the post-development stage.

We argue that MNCs' utilization of political ties enhances product innovation for the following reasons: First, information asymmetries are a major concern in China. Innovation is an information-intensive activity that requires strong information resources. According to the resource-based view, relational capital is a critical 
capability that enhances firms' competitive advantage in product innovation (Barney 1991). Political ties with different levels of governmental agencies thus contribute to the relational capital that helps MNCs to reduce information asymmetries by gaining market information and knowledge. Political ties therefore help them with opportunity recognition and realization and facilitates their ability to innovate. Second, a firm's political ties serve as an effective mechanism of relational governance and knowledge appropriation in China ( $\mathrm{Li}$ et al. 2008). Weak institutional IPR protection in China adds a significant risk to MNC subsidiaries' innovation activities. MNCs can gain the institutional protection needed to make returns on their investments in innovation activities, through political ties with government agencies, because political ties can serve as an alternative IPR enforcement mechanism (Sun et al. 2010). Hence, we predict,

H5: Political ties positively affect product innovation.

\subsection{Boundary Conditions of Political Ties}

The research model displayed in Fig. 1 includes two moderator variables, which affect the intensity of the relationship between political ties and product innovation performance, namely, technological dynamism and competitor opportunism.

\subsubsection{Technological Dynamism}

Technological dynamism is defined as the degree of volatility, change and unpredictability related to technology in the environment (Rindfleisch and Heide 1997). Changing technologies provide opportunities to engage in product development, and may force firms to do so in order not to be driven out of markets (Damanpour and Aravind 2006), indicating a direct and positive association between technological change. However, while the previous reasoning establishes a direct link between technological dynamism on the one hand and, political ties and innovation performance on the other, Sheng et al. (2011) point towards a moderating role of technological dynamism for the relationship between political ties and innovation performance. Sheng et al. (2011, p. 5) argue that "political ties may be less effective in conditions of high technological turbulence". Referring to the role of the firm's knowledge and absorptive capacity in relation to tackling challenges posed by technological change, they state that obtaining government-controlled resources through political ties "would not directly improve technological innovation capability". These government-related resources, available at a relatively low cost, may lead the firm to commit fewer resources to R\&D and innovation activities, and also negatively affect innovative corporate cultures (Sheng et al. 2011). Thus, technological dynamism and dynamism may negatively affect the otherwise positive relationship between political ties and innovation performance:

H6: Technological dynamism weakens the positive effect of political ties on product innovation. 


\subsubsection{Competitor Opportunism}

MNCs in emerging markets like China often face significant opportunistic challenges, such as violation of IPR issues or unfair competitive practices or legal systems and practices which favour local firms. MNCs face additional challenges in their interactions with supplying partners, which frequently also serve other domestic or international competitors. Zhang et al. (2017) refer to the notion of dysfunctional competition to reflect the difficulties in offsetting opportunistic or illegal activities which may hamper innovation and firm performance. We use the term 'competitor opportunism' to refer to the degree of positive bias towards local companies or customers in the regulatory environment (Cavusgil et al. 2004).

Taking the view of transaction-cost economics, Cavusgil et al. (2004) argue that, in the face of a high degree of institutional hostility, contractual governance may become less effective. This negatively impacts the appropriability conditions of the supplier, i.e. "the extent to which a firm is able to capture returns from innovations" (Damanpour and Aravind 2006, p. 50). As a relational governance mechanism, political ties become relatively more important for enhancing product innovation as they serve as an alternative mechanism for enforcing intellectual property. This hints at a substitutive relationship between the effectiveness of institutions and political ties. Hence,

H7: Competitor opportunism strengthens the positive effect of political ties on product innovation.

\section{Research Methods}

\subsection{Sample and Survey Development}

Our study focuses on the subsidiaries of foreign-owned MNCs in the automotive industry in China. We chose senior product and project managers from the MNCs as the key informants for this study. The sampling frame consisted of MNCs supplying automobile parts, taken from lists in the Directory of China Automobile and Parts (850 companies), which are produced by different nations' chambers of commerce in China. We restricted our sample to MNCs that met the following criteria: (1) for-profit MNCs potentially in need of both the technical and managerial knowhow of local firms and engaging in product innovation in China, (2) MNCs with only one foreign parent and (3) wholly foreign-owned or international joint ventures. All firms in the database were contacted to assess their eligibility and to determine appropriate informants for the study. Each respondent was asked to specify their most important Chinese customer in terms of largest sales volume.

Data collection was conducted in two stages during 2010 and 2011. In-depth interviews were first conducted with fifteen senior product managers, project managers or directors from the MNC suppliers. This initial qualitative and exploratory approach provided valuable input for the refinement of the questionnaire 
and the adaptation of the key constructs to the industry context. These interviews served as an a priori test of the key constructs with respect to their usefulness and appropriateness. In the second stage, we collected the relevant survey data through different approaches, including mail, telephone and face-to face interviews. The questionnaire was originally developed in English; the translationback-translation method was used to ensure that we had a conceptually equivalent Chinese version (Mullen 1995). The senior managers surveyed answered the questionnaire by choosing their firm's most important Chinese OEM customer and responding to all questions with respect to their firm's relationship with that customer.

Of the 850 firms contacted, a total of 170 useable questionnaires were returned, giving an effective response rate of $20 \%$ (170/850). Among the 170 firms, $49 \%$ were joint ventures, and the other $51 \%$ were foreign parents of subsidiaries. With regards to nationality, the MNCs in our sample came from various countries or regions, including Germany (26\%), Korea (13\%), the United States (12\%), Japan (10\%), France (4\%), Switzerland (3\%), Sweden (2\%), Canada (2\%), the Netherlands (2\%), the United Kingdom (2\%), Taiwan (2\%), Singapore (2\%), Spain (1\%), Hong Kong (1\%), Malaysia (1\%) and others. Also, our sample included suppliers of a variety of key automobile parts and components, with brakes (28\%), chassis $(27 \%)$, motor (26\%) and general electrics (24\%) most frequently represented, next to clutches, petrol sensors, filtration systems, body parts, exhausts, lighting and cooling systems, as well as oil chemicals and batteries. In terms of firm age (years) the mean is 19 years, firm size is close to 2000 with a median of 600 and the number (percentage) of company subsidiaries with positive ROI is $64 \%$ (see Table 1).

We assessed non-response bias by classifying the responses into two groups, early respondents and late respondents (Armstrong and Overton 1977). We checked for the possibility of non-response bias by comparing the respondents with the non-respondents in terms of number of employees, sales volume, and age of company. The results of the ANOVA show that there are no statistically significant differences between the respondents and the non-respondents in any of these aspects $(\mathrm{F}=0.63, \mathrm{p}>0.10 ; \mathrm{F}=0.92, \mathrm{p}>0.10 ; \mathrm{F}=0.77, \mathrm{p}>0.10)$.

A reliable assessment of non-response bias can only be achieved via feedback from the non-respondents themselves. Therefore, we identified a selection of nonrespondents and called them, to obtain explanations for their lack of response. In all cases, the reasons provided to us were related to time pressures in filling out the questionnaire, the general notion that the questionnaire was too demanding

Table 1 Descriptive information

\begin{tabular}{lrrrrr}
\hline & Mean & Median & Min & Max & SD \\
\hline Firm age (years) & 19 & 14 & 3 & 102 & 16 \\
Number of employees (Size) & 1942 & 600 & 30 & 26,000 & 3646 \\
Number of company subsidiaries & 64 & 70 & 0 & 100 & 32 \\
$\quad$ with positive ROI (in \%) & & & & \\
\hline
\end{tabular}


and that other requests for feedback had to be prioritized. While this indicates an element of unidentified non-response bias, the overall findings suggest that nonresponse bias does not pose a significant threat to this study.

\subsection{Measurement}

Multi-item scales and a seven-point response format were used to operationalize all psychometric constructs in the study. The measures were adapted from existing studies, and refined based on feedback from experienced researchers and practitioners in the area of inquiry. The measures are listed in Table 2.

A three-item scale was used to measure political ties. The scales were adapted from Sheng et al. (2011). We used three items to measure product innovation. The scale was adapted from Zhang and $\mathrm{Li}$ (2010) and is primarily concerned with incremental innovation. In order to provide an anchor to help the respondents answer the questions, we asked them to rate the extent to which their ventures were successful relative to those of their major competitors, in terms of (1) improving existing products, (2) lowering product return rates and (3) developing new products to penetrate the market.

Furthermore, a three-item scale was used to measure relation-specific investment; it was taken from Subramani and Venkatraman (2003) and adapted to our context. Technological dynamism was conceptualized to capture product complexity, technological innovation and the rate of technological change in the industry. It was adapted from Celly et al. (1999) and Jaworski and Kohli's (1993) technological turbulence scales. For protection orientation we adapted three items from Rivera-Santos et al. (2012) to describe the extent to which the organizational values and norms emphasized a knowledge protection philosophy and culture. Our measure of competitor opportunism was adapted from Zhang et al. (2003). It contains three items measuring the extent to which the MNC perceives that the environment poses a threat, as characterized by precarious industry circumstances, regulatory violations by competitors and customers, or generally unfavourable conditions beyond the control of the firm.

\subsection{Control Variables}

We also included a set of control variables, namely (1) years of operation in China (age), (2) number of employees (size), (3) organizational mode of operation (mode), (4) location of the headquarter (HQLoc), and (5) past performance. (1) Age: Younger and start-up firms are usually more innovative due to having less bureaucratic structures and less risk-averse behaviour (Zhou et al. 2016). By including a variable measuring the years of operation in China, we expect an inverse relationship between age and innovation performance. First, older foreign operations in China are more likely to be involved in manufacturing activities, as foreign-owned firms have only recently moved from being solidly involved in manufacturing to innovation activities. Second, younger firms may be smaller, less bureaucratic and thus more agile and innovative. (2) Size: Size is operationalized via the number of 


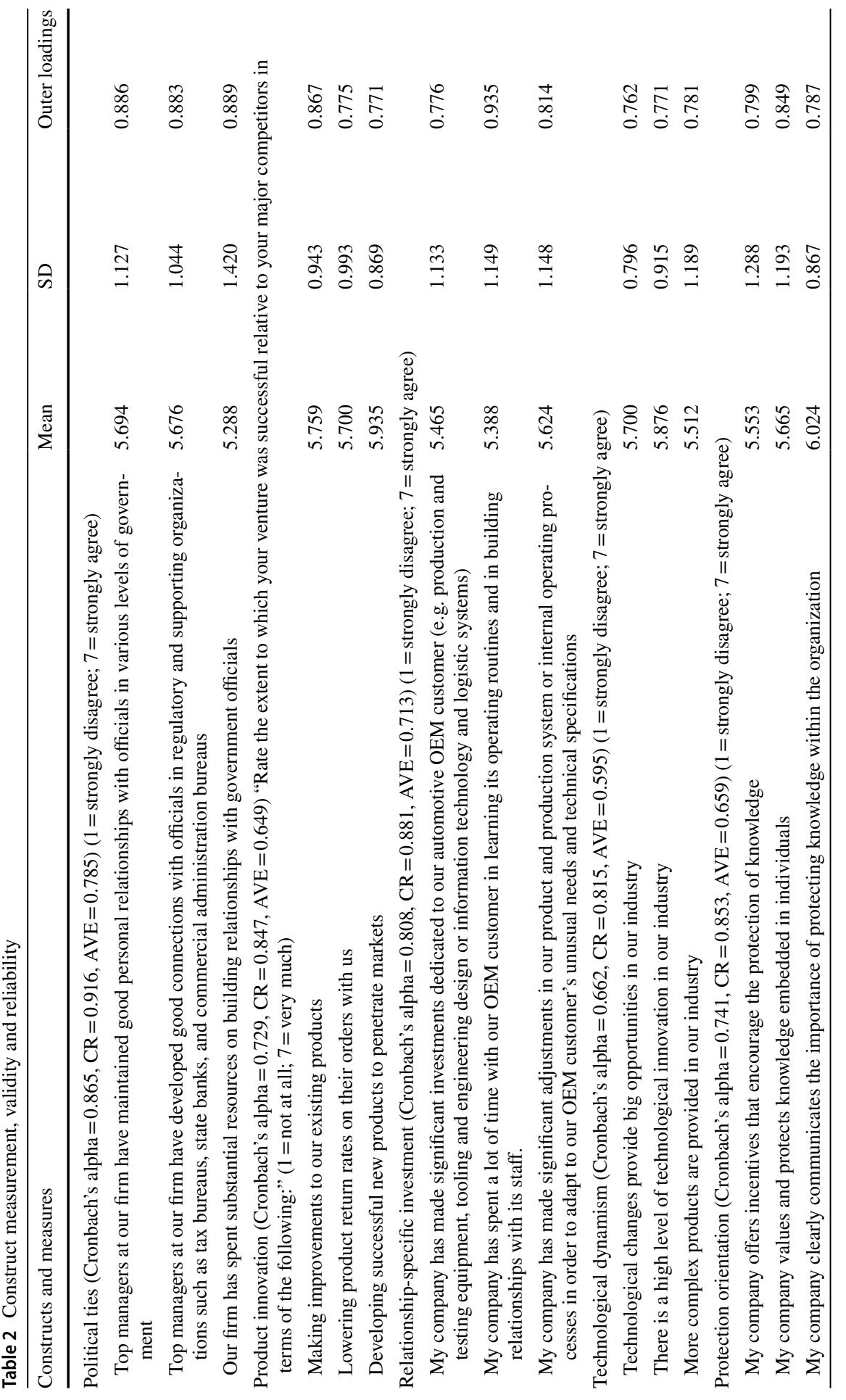




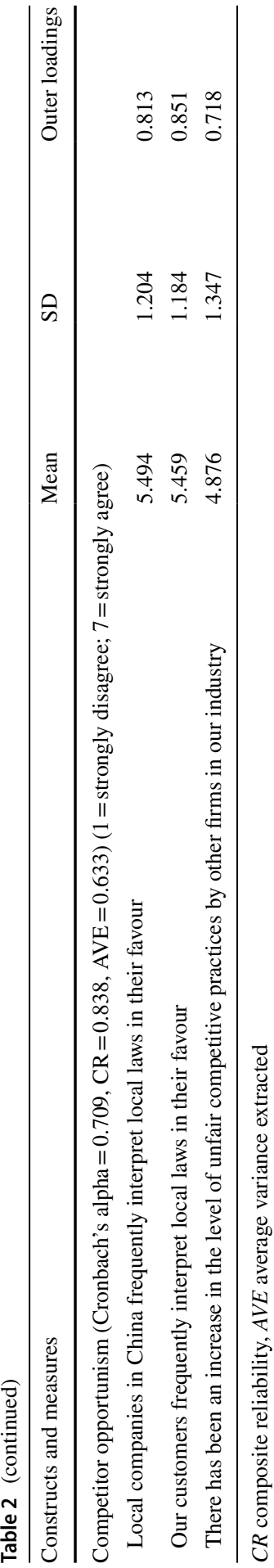


employees. Arguments in relation to the link between product innovation and firm size go in both directions. Small firms are more likely to introduce new products and new production methods by opening new markets and tapping new sources of supply, while larger firms possess more scientific knowledge and management expertise, find it easier to attract scientists and engineers, have better access to capital, possess higher levels of monopoly power and would thus be more willing to invest in innovation (Damanpour and Aravind 2006; Kotabe et al. 2017). (3) Mode: Extant literature has highlighted the importance of mode of operation on firm performance (Puck et al. 2009). Thus, we distinguish between international joint venture (IJV) and wholly foreign-owned enterprise (WFOE). (4) HQ-location and (5) Past performance: Further, previous work has highlighted headquarter location and past financial performance may affect political ties and product innovation (Kotabe et al. 2017; Li and Atuahene-Gima 2001). Past performance was measured on the basis of the question how many of the company's subsidiaries have returned their investment. The respondents were asked to think of their past 5 years investment experience in China. (measured on a percentage scale).

\subsection{Common Method Bias}

As information about different constructs was collected from a single respondent for each company, the potential for a common method variance problem existed. Common method variance was assessed using the methods suggested by Podsakoff et al. (2003). First, as arranging items in an appropriate order in a questionnaire can reduce common method bias in self-reporting, we used different instructions for different scales. The constructs in our model were placed in different sections of the questionnaire, which is useful for balancing respondent's consistency of answers. Second, we followed the analytical procedure proposed by Huigang et al. (2007), with one measurement model including all the traits and the other model adding in a method factor. The results showed that the path coefficients were not much different and the difference was statistically insignificant. Third, we checked the correlation matrix to see if there were any high correlations. Common method bias is unlikely if there are no excessively high correlations (>0.9) (Pavlou et al. 2007). Finally, we used Harman's one-factor rule and partial correlation to assess the potential effect of common method bias (Podsakoff and Organ 1986). The analysis produced seven factors with eigenvalues greater than 1, accounting for $69 \%$ of the variance. Neither a single factor nor a general factor emerged that could account for the majority of the covariance in the measures. The results of these tests suggested that common method bias was unlikely to pose a threat to the results of this study.

\section{Results}

We used partial least squares structural equation modelling (PSL-SEM) to analyse our proposed integrated analytical model, applying SmartPLS 3 software (Ringle et al. 2015). We consider PLS-SEM the most appropriate choice as it is widely 
accepted for examining predictive models at the early stages of theory development (Fornell and Bookstein 1982; Hair et al. 2012; Henseler et al. 2009). As indicated above, to the best of our knowledge, the link between political ties and product innovation in foreign MNC subsidiaries has not previously been studied. In line with Wold (1980) and best practices outlined at early stages of theoretical development (Richter et al. 2016), we used a 'soft-modelling' approach to develop our research model from a broader conceptual frame and then explore previously untested relationships.

As we are not seeking to mimic common factor models and covariance-based structural equation modelling (CB-SEM) results, we consider the PLS approach perfectly suitable for our research objectives (Hair et al. 2017). In addition, PLSSEM imposes minimal requirements on sample size for the achievement of sufficient statistical power (Hair et al. 2012; Lohmöller 1989). Our relatively small sample size of $n=170$ is in line with Reinartz et al. (2009) recommendation to apply PLS when there are less than 250 observations. PLS-SEM furthermore allows to consider both first- and higher-order constructs in terms of the type of variables used, and to include direct and mediated effects among the hypothesized relationships considered. Finally, it allows to simultaneously estimate the relationships of the structural model (inner model) and assess the reliability and validity of the measurement model (outer model) (Barroso et al. 2010; Chin 1998).

In a two-stage approach to operationalizing the multidimensional constructs of political ties and product innovation (Chin 2010; Wright et al. 2012), we first weighed and combined the items for each dimension and created the latent variable scores by running the first-order measurement model. Then, in the second stage, we ran the full structural model to evaluate the structural model results, using the dimensions of the political ties and product innovation constructs as observed indicators of the constructs (Albort-Morant et al. 2016; Wright et al. 2012). This approach has "the advantage of estimating a more parsimonious model on the higher level analysis without needing the lower order constructs" (Becker et al. 2012, p. 366).

\subsection{Measurement Assessment}

The assessment of the internal reliability yielded Cronbach's alpha values of above 0.7 (ranging from 0.709 to 0.865 ) for all constructs except for technological dynamism, which suggests a high level of internal reliability (Fornell and Larcker 1981; Nunnally and Bernstein 1994). With respect to the value of 0.662 for technological dynamism, values above 0.6 are acceptable for exploratory research (Hair et al. 2017). What is more, Cronbach's alpha can be considered the lower bound and the composite reliability (CR) the upper bound of the true internal consistency reliability (Revelle 1979).

Hence, we used the composite reliability (CR) scores used to assess the internal reliability of the latent variables (Werts et al. 1974) and all of those-including technological dynamism-were all above 0.8 , ranging from 0.815 to 0.916 , suggesting sufficient reliability of the composite measurement items (Hair et al. 
2017). The absolute standardized first-order outer loadings of the indicators ranged from 0.718 to 0.935 , all exceeding the critical value of 0.7 (Fornell and Larcker 1981; Nunnally and Bernstein 1994) and minimum cut-off criterion of 0.5 (Anderson and Gerbing 1988; Hair et al. 2011; Henseler et al. 2009). This all indicates a high level of reliability of the measurement in our measurement model.

Confirmatory factor analysis (CFA) was used to assess the convergent and discriminant validity. All average variance extracted (AVE) values are above the recommended value of 0.50 (Table 3 ), ranging from 0.595 to 0.785 , thus confirming convergent validity for the constructs (Fornell and Larcker 1981). Table 3 also shows the correlations of all the constructs.

Discriminant validity is assessed in two ways. First, the Fornell-Larcker criterion compares the square root of AVE of each latent variable with the cross-loadings. A square root of AVE higher than the cross-loadings confirms the discriminant validity of the construct in question (Fornell and Larcker 1981; Hair et al. 2014). Table 3 indicates that all constructs have adequate discriminant validity. Second, an analysis of the heterotrait-monotrait (HTMT) ratio of the correlations shows that all values are below the conservative threshold value of 0.85 , which supports discriminant validity (Henseler et al. 2014). We furthermore computed bootstrap confidence intervals from 5000 bootstrap samples, to check whether the HTMT values were significantly different from 1 (Hair et al. 2017). Neither of the confidence intervals includes the value 1 , demonstrating that the constructs are empirically distinct. This indicates that the constructs have discriminant validity (Hair et al. 2017).

In PLS path modelling, the standardized root mean square residual (SRMR) is the only approximate model-fit criterion and thus goodness-of-fit measure (Henseler et al. 2016; Henseler et al. 2014; Hu and Bentler 1998). Our fit index is 0.075 , which is slightly lower than the 0.08 threshold considered to indicate a good fit for CB-SEM models (Hu and Bentler 1998; Hair et al. 2017) is deemed appropriate in this context.

Table 3 Intercorrelations and shared variances of measures

\begin{tabular}{lllllll}
\hline \multicolumn{7}{c}{ Correlations between constructs } \\
\cline { 2 - 6 } & 1 & 2 & 3 & 4 & 5 & 6 \\
\hline 1. Political ties & $\mathbf{0 . 8 8 6}$ & & & & \\
2. Product innovation & $0.353^{* *}$ & $\mathbf{0 . 8 0 5}$ & & & & \\
3. Relationship-specific investment & $0.320^{* *}$ & $0.195^{* *}$ & $\mathbf{0 . 8 4 4}$ & & & \\
4. Technological dynamism & $0.335^{* *}$ & $0.463^{* *}$ & $0.177^{*}$ & $\mathbf{0 . 7 7 1}$ & & \\
5. Protection orientation & $0.361^{* *}$ & $0.308^{* *}$ & $0.178^{*}$ & $0.198^{* *}$ & $\mathbf{0 . 8 1 2}$ \\
6. Competitor opportunism & $0.451^{* *}$ & $0.290^{* *}$ & $0.371^{* *}$ & $0.388^{* *}$ & $0.386^{* *}$ & $\mathbf{0 . 7 9 6}$ \\
\hline
\end{tabular}

$\mathrm{N}=170$, correlations are shown in the lower triangle of the matrix

**Correlation is significant at the 0.01 level (2-tailed)

*Correlation is significant at the 0.05 level (2-tailed). Bold numbers on the diagonal denote the square roots of average variance extracted (AVE) 


\subsection{Structural Model Results}

The assessment of the structural model included an evaluation of its predictive power, using $R^{2}$ scores. $\mathrm{R}^{2}$ scores indicate predictive power by showing the amount of variance explained by the independent variables (Peng and Lai 2012). The results of the structural model are shown in Table 5. Since the objective of PLS is to maximize variance explained, $\mathrm{R}^{2}$ - as a prediction-oriented measure-is used to evaluate PLS models. Our model explains $32.2 \%$ of the variance in political ties and $31.5 \%$ of the variance in product innovation, which are considered moderate levels (Cohen 1988; Ringle et al. 2012). Acceptable $R^{2}$ values very much depend on the research context; for instance, a $R^{2}$ value of 0.2 is accepted as high in some disciplines, such as consumer behaviour (Hair et al. 2011). Given that our approach is building on soft-modelling and exploratory model evaluation rather than confirming results from previous studies (Richter et al. 2016; Wold 1980), we hold that our $R^{2}$ values are acceptable.

In addition to evaluating the $R^{2}$ values of all endogenous constructs, the change in the $R^{2}$ value when a specified exogenous construct is omitted from the model can be used to evaluate whether the omitted construct has a substantive impact on the endogenous construct. The measures is referred to as the effect size $\left(f^{2}\right)$ and is used to examine the impact of an independent latent variable on a dependent latent variable (Chin 2010). It is calculated as $f^{2}=\left(R_{\text {included }}^{2}-R_{\text {excluded }}^{2}\right) /\left(1-R_{\text {included }}^{2}\right)$, where $R_{\text {included }}^{2}$ and $R_{\text {excluded }}^{2}$ are the $R^{2}$ values of the endogenous latent variable when a selected exogenous latent variable is included in or excluded from the model. $f^{2}$ values of $0.02,0.15$ and 0.35 are used to indicate that a predictor latent variable has a small, medium or large effect size at the structural level (Chin 2010; Cohen 1988). The effect size of political ties on product innovation is small $\left(f^{2}=0.045\right)$, technological dynamism on product innovation is at the medium level $\left(f^{2}=0.168\right)$. The effect sizes for the moderators on political ties are also at the small level (see Table 4), but within the median of effect size of the past 30 years of management research (Aguinis et al. 2005).

Further, we ran blindfolding tests to assess the predictive relevance of the path model with regard to each endogenous construct (Hair et al. 2017). Stone-Geisser's $Q^{2}$ value for political ties and product innovation are both above zero, thus

Table 4 Determination coefficient, predictive relevance and effect sizes

\begin{tabular}{|c|c|c|c|c|c|}
\hline & $\begin{array}{l}\text { Coefficient of } \\
\text { determination } \\
\left(R^{2}\right)\end{array}$ & Political ties $\left(f^{2}\right)$ & $\begin{array}{l}\text { Product } \\
\text { innovation } \\
\left(f^{2}\right)\end{array}$ & $\begin{array}{l}\text { Predictive } \\
\text { relevance } \\
\left(Q^{2}\right)\end{array}$ & Effect size $\left(q^{2}\right)$ \\
\hline Political ties & 0.322 & & 0.045 & 0.213 & 0.104 \\
\hline $\begin{array}{l}\text { Competitor opportun- } \\
\text { ism }\end{array}$ & & 0.053 & 0.005 & & 0.136 \\
\hline $\begin{array}{l}\text { Technological dyna- } \\
\text { mism }\end{array}$ & & 0.037 & 0.168 & & 0.049 \\
\hline Product innovation & 0.315 & & & 0.163 & \\
\hline
\end{tabular}


Table 5 Test of hypothesized relationships: beta coefficients and t-values

\begin{tabular}{lll}
\hline Variables & Political ties & Product innovation \\
\hline Independent variables & & \\
Protection orientation & $0.200^{* * *}$ & \\
Relationship specific investment & $0.147^{* *}$ & \\
Competitor opportunism & $0.234^{* *}$ & 0.073 \\
Technological dynamism & $0.172^{* *}$ & $0.377^{* * *}$ \\
Political ties & & $0.211^{* *}$ \\
Moderating effects & & \\
Competitor opportunism $\times$ political ties & & $0.139^{* *}$ \\
Technological dynamism $\times$ political ties & & $-0.133^{*}$ \\
Control variables & & \\
Age & $0.114^{*}$ & 0.079 \\
Mode & $-0.106^{*}$ & 0.041 \\
Size & 0.027 & -0.043 \\
HQLoc & 0.027 & -0.021 \\
Past performance & 0.070 & 0.066 \\
Model parameters & & 0.315 \\
$\mathrm{R}^{2}$ & 0.322 & 0.272 \\
$\mathrm{R}^{2}$ & 0.283 & \\
Observations & 170 & \\
SRMR & 0.071 & \\
\hline & & \\
\hline
\end{tabular}

Age years of operations in China, Mode operations mode (organizational arrangement as international joint venture 'IJV' or wholly foreign owned enterprise 'WFOE'), HQLoc headquarter location (Asia or outside Asia), Past performance \% of subsidiaries with positive ROI), SRMR standardized root-mean square residual measure of model fit (Henseler et al. 2014)

$* \mathrm{P}<0.1, * * \mathrm{P}<0.05, * * * \mathrm{P}<0.01$

supporting the model's predictive relevance regarding the endogenous latent variables. We also calculated the $q^{2}$ effect size, which reflects an exogenous construct's contribution to an endogenous latent variable's $Q^{2}$ value (Hair et al. 2017). Similar to $f^{2}$, it is a relative measure of predictive relevance and $q^{2}$ values of $0.02,0.15$, and 0.35 , respectively, indicate that an exogenous construct has a small, medium, or large predictive relevance for a certain endogenous construct. The effect size $q^{2}$ values of political ties, competitor opportunism and technological dynamism are found to be at small to medium levels. Table 4 provides the relevant coefficient values and effect sizes of the structural model.

\subsection{Hypothesis Testing}

The assessment of PLS models involves the estimation of path loadings and $\mathrm{R}^{2}$ values. Path loadings indicate the strength of the relationships between independent and dependent variables. We used a bootstrapping technique to statistically test the hypotheses in our model. This allowed us to assess the path coefficients' 
significance (Henseler et al. 2009). PLS-SEM applies a nonparametric form of bootstrapping (we used 5000 resamples) through which standard errors and t-statistics are obtained to assess the significance statistics of the hypothetical relationships, and does not presume a normal data distribution (Hair et al. 2011).

The path coefficient from political ties to product innovation is 0.211 $(p<0.05)$, which supports H5. The moderating effect of technological dynamism on the relationship between political ties and product innovation is -0.133 $(\mathrm{p}<0.1)$, which supports H6. The moderating effect of competitor opportunism on the relationship between political ties and product innovation is 0.139 $(\mathrm{p}<0.05)$, which supports H7. The path coefficient from protection orientation to political ties is 0.200 ( $\mathrm{p}<0.01)$, which supports $\mathrm{H} 1$. The path coefficient from relationship-specific investment to political ties is $0.147(\mathrm{p}<0.05)$, which supports $\mathrm{H} 2$. The path coefficient from technological dynamism to political ties is 0.172 ( $p<0.05$ ), which supports H3. The path coefficient from competitor opportunism to political ties is $0.234(\mathrm{p}<0.01)$. This supports a positive relationship between competitor opportunism and political ties (H4).

Overall, the results indicate that political ties are a significant driver of product innovation, and that specific organizational factors, such as protection orientation and relationship-specific investment—both potentially a response to the threat of opportunism - and environmental factors, such as a hostile legal environment and technological dynamism, push MNC subsidiaries to invest in political ties in order to improve organizational performance, here in the form of product innovation. The results of the hypothesis testing are summarized in Table 5 below.

In our analysis, we controlled for the location of headquarter (HQLoc) to distinguish between headquarters located in eastern/Asian countries and headquarters located in western countries. The thinking was that due to cultural and geographical proximity, companies from Asian countries would know the Chinese system and the respective requirements of political ties better than 'western' firms and thus 'invest' more in political ties. However, in our analysis, the location of HQs variable turns out to be insignificant (but in the right direction). We also controlled for years of operation in China (age), market entry/operations mode (mode), and size (in terms of employees). For age and mode, we obtained marginally significant $(\mathrm{p}<0.1)$ results for political ties. This could suggest that the longer a business has been operating in China, the higher are political ties. Second, compared to wholly-owned subsidiaries, joint ventures may have more intensive political ties. The latter may be related to the fact that until China's WTO accession in 2001, foreign companies could only enter Chinese markets by establishing joint ventures with the Chinese partner company. The Chinese partner, either a public-sector company or a privately-owned company with very close links to the Communist Party, would be responsible for the political links. The positive association between age of operations and political ties may be a consequence of learning effects of companies operating in the Chinese market. Over time, companies would learn about the importance of establishing and maintaining political ties. Given the marginal significance of these controls, further research might be useful, however. 


\section{Discussion}

With the increase in global innovation outsourcing and a significant shift towards supplier-driven innovation networks and open innovation, suppliers are now playing key roles in innovation generation in global supply chains. Globally, but also in the automotive industry, supplier MNCs are increasingly engaging in product innovation activities in their emerging market subsidiaries (Veldhoen et al. 2014; Zhou et al. 2017). However, weak institutions in emerging markets, especially with respect to knowledge management and the protection of IPR, pose a challenge to the MNC subsidiaries. Furthermore, governments in emerging economies play an active and interventionist role in the respective national business systems. This is particularly true for the Communist-Party-led government in the socialist market economy of China (Heilmann 2016; Zhang and Zhang 2014). As a consequence, MNCs have established and maintain political ties with government authorities in order to get access to information relevant to their business activities, as well as to engage in relational activities to further their interests, similarly to Chinese companies (Zhang and Zhang 2014).

This study investigated the antecedents and product innovation implications of political ties of foreign automotive component supplier MNC subsidiaries in China. Drawing on transaction-cost economics, resource-based theory and the institutional approach, we developed and empirically tested an integrative analytical model that delineates the antecedents of political ties and product innovation implications. This study broadens and deepens our understanding of how and why MNCs develop political networking in China and of the respective innovation implications. Below, we discuss the results of this study.

\subsection{Drivers of MNCs' Utilization of Political Ties}

Shi et al. (2014) argue that political ties are especially relevant in state-capitalist political economies and business systems such as China, which emulates institutional elements of the market economy but at its core is centrally controlled by the Communist Party, its government and its agencies. This leads to firms' dependence on the government for critical information, resources, legitimacy and support.

Prior research has separately investigated the external and internal drivers of firms' utilization of political ties (Li 2005; Sun et al. 2012). However, to the best of our knowledge, research which develops an integrated model to simultaneously examine both internal and external drivers of political ties is missing. Our empirical findings show that internal factors such as protection orientation and external factors including relation-specific investment and technological dynamism motivate MNCs' utilization of political ties in China.

Among the three drivers included in our model, we find that the effects of competitor opportunism - an external driver - are greater than the effects of relationship-specific investment or protection orientation. This points towards the important role of certain characteristics of the business system for the establishment and maintenance of political ties. Many of the foreign companies in our sample perceive 
the legal institutional environment in China as inadequate and complain about unequal treatment from the Chinese government compared with that afforded their local competitors. Specifically, in the innovation generation process, the inefficient IPR enforcement mechanism may pose significant risks for MNCs. When MNCs face high levels of hostility in emerging markets, product innovation strategies become riskier and increasingly challenging due to the lack of sufficient protection for innovative outputs.

The results of our analysis show that the degree of hostility in the legal and institutional environment is positively associated with investing in and maintaining political ties. In China, foreign MNCs appear to have shifted from passive to proactive in terms of their development of government relationships. This is consistent with Luo's (2007) arguments that MNCs must shift away from capability transfer to develop new capabilities - for example political ties as non-market capabilities-in emerging markets such as China.

Drawing on transaction-cost economics, the findings demonstrate that political ties can serve as a relational governance mechanism in dealing with transactional hazards arising from relationship-specific investments and competitor opportunism. At this point, it is important to remember that the construct of competitor opportunism involves items related to opportunistic interpretation of the legal situation by customers, violations of property rights and unfair competitive practices. This very much relates to Williamson (1975) and his notion of opportunistic behaviour.

Relationship-specific investment incurs hold-up risks and MNCs can mitigate this risk by deploying a relational governance strategy. The findings are consistent with the relational governance literature and suggest that political ties can serve as an alternative approach to contractual governance (Sheng et al. 2011). Political ties may function as insurance vis-a-vis opportunistic threats in an environment which has yet to introduce the rule of law.

Our research also finds that protection orientation enhances MNCs' utilization of political ties. Weak institutions in China shape MNCs' knowledge management culture and processes, in the direction of a knowledge protection orientation. Previous work has highlighted the dimension of learning orientation and intent in the knowledge management process. However, protection orientation as a firm's strategic orientation has received little attention in previous research (Rivera-Santos et al. 2012). This research provides initial evidence of the link between protection orientation and political ties.

\subsection{Product Innovation Outcomes of Political Ties}

Research results on the link between political ties and firm performance in emerging markets are mixed and inconclusive (Sun et al. 2012). Some studies show that political ties have a positive effect on firm performance through the enhancement of legitimacy, the gaining of institutional support and the identification of opportunities, while other work finds that political ties may have a negative effect on firm performance due to over-embeddedness and government intervention ( $\mathrm{Li}$ et al. 2009; Sun et al. 2010). Additional research on the contingencies with respect to the impact 
of political ties on firm performance points to important influences from firm ownership (Peng and Luo 2000), environmental uncertainty (Li and Zhang 2007), institutional support (Sheng et al. 2011), competitor opportunism (Li and Zhang 2007) and task orientation (Zhang et al. 2014).

The results of our study show a positive and significant relationship between the MNCs' political ties and product innovation in China. Political ties can serve as an alternative governance and knowledge appropriation mechanism which helps MNCs obtain relevant information and protect their intellectual property and interests, which in turn enhances product innovation. Recent work shows that political ties play an important role in Chinese firms' innovation generation (Kotabe et al. 2017). Our results complement this perspective and suggest that the value of political ties is also critical for the product innovation performance of foreign MNCs in China.

Our empirical analysis also shows that the relationship between political ties and product innovation performance is moderated by two variables related to the firms' external environment. Competitor opportunism positively reinforces the importance of the impact of political ties on product innovation. This is line with empirical findings by Oke et al. (2012) who demonstrate in the context of human resource policy, that environmental uncertainty positively moderates the innovation strategy execution-innovation performance relationship. In addition, technological dynamism negatively affects the otherwise positive relationship between political ties and innovation performance. This finding also mirrors the empirical results of Sheng et al. (2011).

\subsection{Managerial Implications}

This research provides important implications for practitioners. It demonstrates how MNCs can mitigate risk arising from an inadequate institutional environment in China by developing political ties with government officials. MNCs' utilization of political ties can serve as an alternative governance mechanism and non-market capability, helping them gain legitimacy and protection as well as valuable resources for the innovation generation process.

As for MNC managers, our results also show that MNCs' political ties are driven by external and internal factors. Specifically, relation-specific investment involves adaptation and transaction risks, which motivate the utilization of political ties to reduce transaction costs. In addition, a protection orientation is a strategic orientation with practical relevance for MNCs' utilization of political ties in China. MNCs' managers should be aware of this strategic orientation given the importance of nurturing political ties in China.

\subsection{Limitations and Future Research Directions}

The results of this study should be interpreted in the light of several inherent limitations. First, we only focus on one type of innovation as an ultimate outcome of political ties. Future research may examine other types of innovation, such as incremental and radical innovation. Furthermore, other types of strategic orientation, 
such as market or entrepreneurial orientation, which may drive MNCs' utilization of political ties, deserve further attention in future research.

Another limitation of this study is its cross-sectional design. Although the results reveal the drivers and performance outcomes of political ties, the causality is only implied. Future studies could overcome this limitation by using longitudinal data.

The empirical context of this study is China. The results may not be applicable to other emerging markets. Future research may extend and replicate the results of this study into different emerging markets. Furthermore, China as a country is a complex entity. For example, competitor opportunism may vary across geographic regions, not least because of their different levels of development of economic, political and social institutions (Zhou et al. 2016).

Last but not least, as there is increasing empirical evidence of the link between political ties and business performance, research on the differential impact of different types of political ties (Zhang and Zhang 2014) would help to advance a more nuanced understanding of the issue.

MNCs in emerging markets are increasingly moving from manufacturing to conducting R\&D and engaging in innovation activities. Establishing, maintaining and using political ties may provide them with access to relevant information and the social legitimacy to operate in emerging markets, with support for doing business, and with relational governance mechanisms in the face of weakly developed institutions with respect to knowledge management and IPR protection. Further research is needed in relation to cross-country variation, institutional change, strategic choices and the related performance implications of different types of political ties of foreign MNCs in emerging markets.

\subsection{Conclusion}

Competitive pressures drive MNEs to operate in multiple international markets and we witness growing government influences on firm decisions across a wide range of issues such as environmental protection and tax issues (Mack et al. 2016). Firms' non-market activities, including such items such as political actions, have become critical elements for MNC growth and survival strategies in international markets (Voinea and Kranenburg 2017). This study addresses this important issue and discusses MNCs' political ties in China in terms of antecedents and innovation outcomes of MNCs' political ties. Drawing on different theoretical perspectives and based on global automotive suppliers in China, this study examines the positive impact of political ties, in terms of enhancing foreign MNCs' product innovation performance in China. Furthermore, the study shows that the extent to which foreign suppliers invest in and maintain political ties is driven by a mix of organizational and environmental factors, namely protection orientation, relationship-specific investment, technological dynamism and competitor opportunism.

Acknowledgements We gratefully acknowledge support from Thomas Hiebaum in the data collection and comments received from Yusuf Kurt, Mo Yamin, Alexander Mohr, Jonas Puck, the editor Joachim Wolf and two anonymous reviewers. Financial support was received from the Alliance Manchester 
Business School (AMBS) Lord Alliance strategic research investment fund [LA-SRIF AA14179]. The authors are thankful to the late Ray Walmsley for his operational research support.

Open Access This article is distributed under the terms of the Creative Commons Attribution 4.0 International License (http://creativecommons.org/licenses/by/4.0/), which permits unrestricted use, distribution, and reproduction in any medium, provided you give appropriate credit to the original author(s) and the source, provide a link to the Creative Commons license, and indicate if changes were made.

\section{Appendix}

As suggested by one of the reviewers, we ran different preliminary research models, i.e. (1) a baseline model with political ties, product innovation and the control variables (see Fig. 2), (2) the full model without moderator variables (see Fig. 3) and (3)

Fig. 2 Baseline model-innovation, political ties and controls only
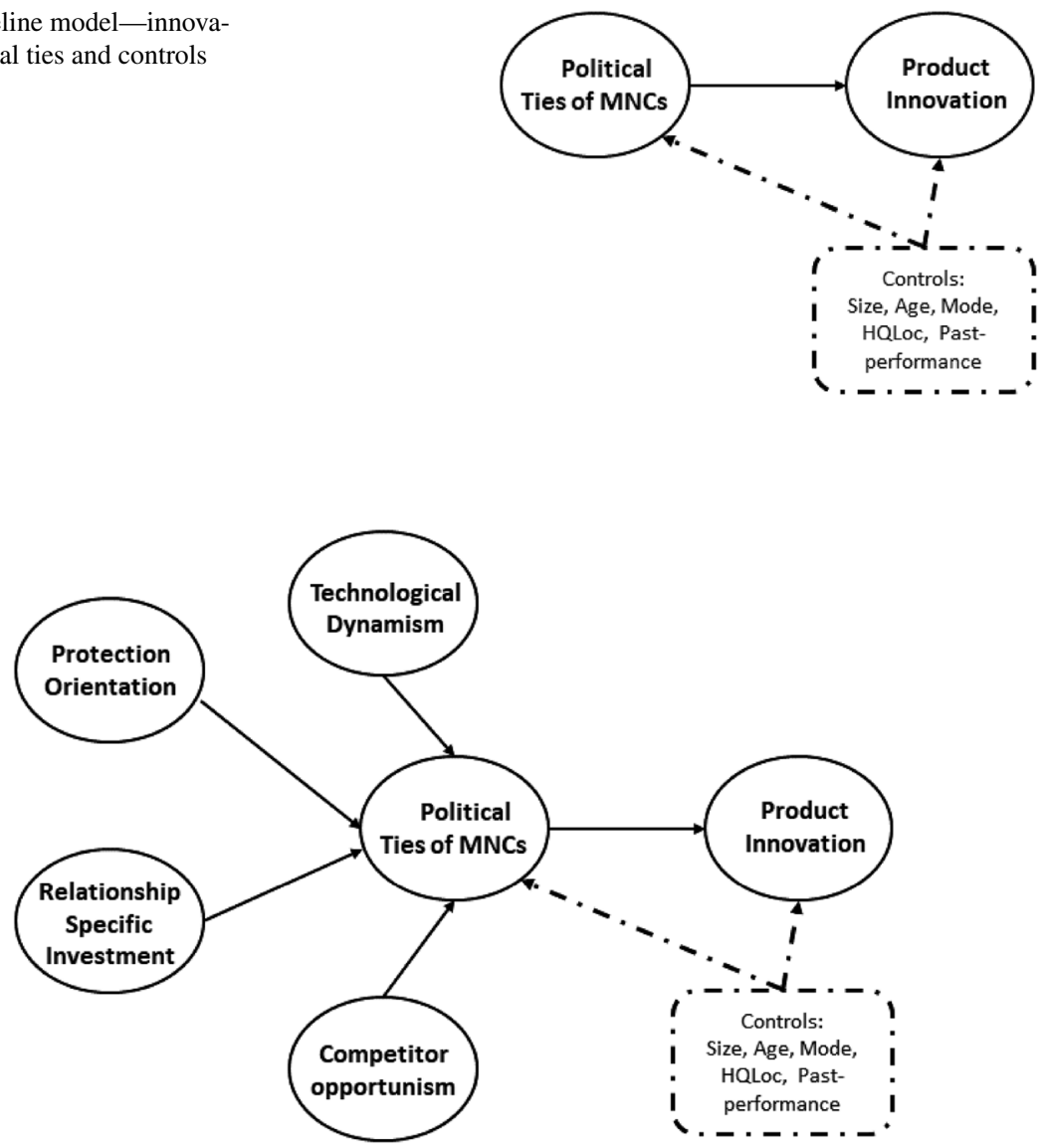

Fig. 3 Full model without moderators 
the full model with moderator variables (as depicted in Fig. 1 of the manuscript). The estimated coefficients and the p-values are included.

As we move from Model 1 to Model 2, the $\mathrm{R}^{2}$-values for political ties and product innovation increase. As we move from Model 2 to Model 3 (our final model in the paper), the $\mathrm{R}^{2}$ for political ties remains constant, and the $\mathrm{R}^{2}$ for product innovation increases.

Following the PLS-SEM philosophy outlined in the paper, this is in line with expectations, as the first step in the method involves the testing of the measurement model and the second step involves the assessment of the structural model (Henseler et al. 2009; Richter et al. 2016). In Model 3 we also report the standardized root-mean square residual measure of model fit (SRMR), which is a well-known 'absolute goodness of fit measure' from covariance-based SEM (CB-SEM), defined as the root mean square discrepancy between the observed correlations and the model-implied correlations. According to Henseler et al. (2014) our model exhibits a good fit (Table 6).

We also revisited the issue of location of headquarter and recoded the respective variable 'HQLoc' to distinguish between headquarters located in eastern/Asian countries and headquarters located in western countries. It has been recoded to $0=$ Headquarter of the MNE in an Asian country and 1 for HQ of the MNE in a nonAsian country (actually all in Western countries). The argument is that due to cultural and geographical proximity, companies from Asian countries would know the Chinese system and the respective requirements of political ties better than 'western' firms and thus 'invest' more in political ties. However, in our analysis, the location of HQs variable turns out to be insignificant (but in the right direction).

Table 6 Full model without moderators

\begin{tabular}{|c|c|c|c|c|}
\hline \multirow[t]{2}{*}{ Dependent } & \multicolumn{2}{|l|}{ Model 1} & \multicolumn{2}{|l|}{ Model 2} \\
\hline & Political ties & Product innovation & Political ties & Product innovation \\
\hline \multicolumn{5}{|l|}{ Independent variables } \\
\hline Political ties & & $0.347 * * *$ & & $0.186^{* * *}$ \\
\hline \multicolumn{5}{|l|}{ Direct effects } \\
\hline Protection orientation & & & $0.200 * * *$ & \\
\hline Relationship specific investment & & & $0.147 * *$ & \\
\hline Competitor opportunism & & & $0.234 * * *$ & \\
\hline Technological dynamism & & & $0.172 * *$ & \\
\hline \multicolumn{5}{|l|}{ Control variables } \\
\hline Age & 0.078 & 0.048 & $0.114 *$ & 0.083 \\
\hline Mode & $-0.152 * *$ & $0.056-$ & $-0.106^{*}$ & 0.053 \\
\hline Size & -0.025 & -0.047 & 0.027 & -0.02 \\
\hline HQLoc & 0.048 & -0.047 & 0.027 & -0.024 \\
\hline Past performance & $0.193 * * *$ & 0.115 & 0.070 & 0.083 \\
\hline $\mathrm{R}^{2}$ & 0.07 & 0.154 & 0.322 & 0.277 \\
\hline Adj. $\mathrm{R}^{2}$ & 0.042 & 0.123 & 0.283 & 0.241 \\
\hline
\end{tabular}

Age years of operations in China, Mode operations mode (organizational arrangement as international joint venture 'IJV' or wholly foreign owned enterprise 'WFOE'), HQLoc headquarter location (Asia or outside Asia), Past performance $\%$ of subsidiaries with positive ROI)

$* \mathrm{P}<0.1, * * \mathrm{P}<0.05, * * * \mathrm{P}<0.01$ 
Moving from baseline Model 1 to the Models 2 and 3, past performance becomes insignificant and the newly introduced variables, except for location of headquarter (HQLoc) and insignificant with respect to either political ties or product innovation or both. Interestingly, two other control variables, years of operation in China (age) and market entry/operations mode (mode), yield (marginally) significant and interesting results. First, the longer a business has been operating in China, the higher up are political ties. Second, compared to wholly-owned subsidiaries, joint ventures have more intensive political ties.

The latter may be related to the fact that until China's WTO accession in 2001, foreign companies could only enter Chinese markets by establishing joint ventures with the Chinese partner company. The Chinese partner, either a public-sector company or a privately-owned company with very close links to the Communist Party, would be responsible for the political links.

The positive association between age of operations and political ties may be a consequence of learning effects of companies operating in the Chinese market. Over time, companies would learn about the importance of establishing and maintaining political ties.

\section{References}

Aguinis, H., Beaty, J. C., Boik, R. J., \& Pierce, C. A. (2005). Effect size and power in assessing moderating effects of categorical variables using multiple regression: A 30-year review. Journal of Applied Psychology, 90(1), 94-107.

Albort-Morant, G., Leal-Millán, A., \& Cepeda, C. G. (2016). The antecedents of green innovation performance: A model of learning and capabilities. Journal of Business Research, 69(11), 4912-4917.

Anderson, J. C., \& Gerbing, D. W. (1988). Structural equation modeling in practice: A review and recommended two-step approach. Psychological Bulletin, 103(3), 411-423.

Armstrong, J. S., \& Overton, T. S. (1977). Estimating nonresponse bias in mail surveys. Journal of Marketing Research, 14(3), 396-402.

Arnoldi, J., \& Villadsen, A. R. (2015). Political ties of listed Chinese companies, performance effects, and moderating institutional factors. Management and Organisation Review, 11(2), 217-236.

Barnes, B. R., Yen, D., \& Zhou, L. (2011). Investigating guanxi dimensions and relationship outcomes: Insights from sino-anglo business relationships. Industrial Marketing Management, 40(4), $510-521$.

Barney, J. (1991). Firm resources and sustained competitive advantage. Journal of Management, 17(1), 99-120.

Barroso, C., Carrión, G. C., \& Roldán, J. L. (2010). Applying maximum likelihood and PLS on different sample sizes: Studies on servqual model and employee behavior model. In V. Esposito Vinzi, W. W. Chin, J. Henseler, \& H. Wang (Eds.), Handbook of partial least squares: Concepts, methods and applications (pp. 427-447). Berlin: Springer.

Becker, J.-M., Klein, K., \& Wetzels, M. (2012). Hierarchical latent variable models in PLS-SEM: Guidelines for using reflective-formative type models. Long Range Planning, 45(5-6), 359-394.

Brander, J. A., Cui, V., \& Vertinsky, I. (2017). China and intellectual property rights: A challenge to the rule of law. Journal of International Business Studies, 48(7), 908-921.

Cavusgil, S. T., Deligonul, S., \& Zhang, C. (2004). Curbing foreign distributor opportunism: An examination of trust, contracts, and the legal environment in international channel relationships. Journal of International Marketing, 12(2), 7-27.

Celly, K. S., Spekman, R. E., \& Kamauff, J. W. (1999). Technological uncertainty, buyer preferences and supplier assurances: An examination of Pacific rim purchasing arrangements. Journal of International Business Studies, 30(2), 297-310. 
Chin, W. W. (1998). The partial least squares approach to structural equation modeling. In G. A. Marcoulides (Ed.), Modern methods for business research (pp. 295-336). New York: Taylor and Francis Group.

Chin, W. W. (2010). How to write up and report PLS analyses. In V. Esposito Vinzi, W. W. Chin, J. Henseler, \& H. Wang (Eds.), Handbook of partial least squares: Concepts, methods and applications (pp. 655-690). Berlin: Springer.

Cohen, J. (1988). Statistical power analysis for the behavioral sciences (2nd ed.). Hillsdale: Lawrence Erlbaum.

Damanpour, F., \& Aravind, D. (2006). Product and process innovations: A review of organizational and environmental determinants. In J. Hage \& M. Meeus (Eds.), Innovation, science and institutional change-A research handbook (pp. 38-65). Oxford: Oxford University Press.

Duncan, R. B. (1972). Characteristics of organizational environments and perceived environmental uncertainty. Administrative Science Quarterly, 17(3), 313-327.

Eisenhardt, K. M., \& Tabrizi, B. N. (1995). Accelerating adaptive processes: Product innovation in the global computer industry. Administrative Science Quarterly, 40(1), 84-110.

Fornell, C., \& Bookstein, F. L. (1982). Two structural equation models: Lisrel and PLS applied to consumer exit-voice theory. Journal of Marketing Research, 19(4), 440-452.

Fornell, C., \& Larcker, D. F. (1981). Evaluating structural equation models with unobservable variables and measurement error. Journal of Marketing Research, 18(1), 29-50.

Govindarajan, V., \& Ramamurti, R. (2011). Reverse innovation, emerging markets, and global strategy. Global Strategy Journal, 1(3-4), 191-205.

Grant, R. M., \& Baden-Fuller, C. (2004). A knowledge accessing theory of strategic alliances. Journal of Management Studies, 41(1), 61-84.

Gu, S., Schwaagserger, S., \& Lundvall, B.-A. (2016). China's innovation system: Ten years on. Innovation: Organization and Management, 18(4), 441-448.

Hair, J. F., Black, W. C., Babin, B. J., \& Anderson, R. E. (2014). Multivariate data analysis (7th ed.). Upper Saddle River: Pearson.

Hair, J. F., Hult, G. T. M., Ringle, C. M., \& Sarstedt, M. (2017). A primer on partial least squares structural equation modeling (PLS-SEM) (2nd ed.). Thousand Oaks: Sage Publications.

Hair, J. F., Ringle, C. M., \& Sarstedt, M. (2011). PLS-SEM: Indeed a silver bullet. Journal of Marketing Theory and Practice, 19(2), 139-152.

Hair, J. F., Sarstedt, M., Pieper, T. M., \& Ringle, C. M. (2012). The use of partial least squares structural equation modeling in strategic management research: A review of past practices and recommendations for future applications. Long Range Planning, 45(5), 320-340.

Heilmann, S. (2016). China's political system. Lanham: Rowman and Littlefield Publishers.

Henseler, J., Dijkstra, T. K., Sarstedt, M., Ringle, C. M., Diamantopoulos, A., Straub, D. W., et al. (2014). Common beliefs and reality about partial least squares: Comments on rönkkö \& evermann (2013). Organizational Research Methods, 17(2), 182-209.

Henseler, J., Hubona, G., \& Ray, P. A. (2016). Using PLS path modeling in new technology research: Updated guidelines. Industrial Management and Data Systems, 116(1), 2-20.

Henseler, J., Ringle, C. M., \& Sinkovics, R. R. (2009). The use of partial least squares path modeling in international marketing. In R. R. Sinkovics \& P. N. Ghauri (Eds.), Advances in international marketing (Vol. 20, pp. 277-320). Emerald: Bingley.

Hitt, M. A., \& Xu, K. (2016). The transformation of China: Effects of the institutional environment on business actions. Long Range Planning, 49(5), 589-593.

Hotho, J. J., Lyles, M. A., \& Easterby-Smith, M. (2015). The mutual impact of global strategy and organizational learning: Current themes and future directions. Global Strategy Journal, 5(2), 85-112.

Hu, G. (2017). The cost of development in China. Berlin: Springer.

Hu, L.-T., \& Bentler, P. M. (1998). Fit indices in covariance structure modeling: Sensitivity to underparameterized model misspecification. Psychological Methods, 3(4), 424-453.

Huigang, L., Saraf, N., Qing, H., \& Yajiong, X. (2007). Assimilation of enterprise systems: The effect of institutional pressures and the mediating role of top management. MIS Quarterly, 31(1), 59-87.

Jaworski, B. J., \& Kohli, A. K. (1993). Market orientation: Antecedents and consequences. Journal of Marketing, 57(3), 53.

Kale, P., Singh, H., \& Perlmutter, H. (2000). Learning and protection of proprietary assets in strategic alliances: Building relational capital. Strategic Management Journal, 21(3), 217-237. 
Kotabe, M., Jiang, C. X., \& Murray, J. Y. (2017). Examining the complementary effect of political networking capability with absorptive capacity on the innovative performance of emerging-market firms. Journal of Management, 43(4), 1131-1156.

Lawton, T. C., \& Rajwani, T. (2015). The Routledge companion to non-market strategy. London: Routledge, Taylor and Francis Group.

Li, J. J. (2005). The formation of managerial networks of foreign firms in China: The effects of strategic orientations. Asia Pacific Journal of Management, 22(4), 423-443.

Li, H., \& Atuahene-Gima, K. (2001). Product innovation strategy and the performance of new technology ventures in China. Academy of Management Journal, 44(6), 1123-1134.

Li, J. J., Poppo, L., \& Zhou, K. Z. (2008). Do managerial ties in China always produce value? Competition, uncertainty, and domestic vs. foreign firms. Strategic Management Journal, 29(4), 383-400.

Li, H., \& Zhang, Y. (2007). The role of managers' political networking and functional experience in new venture performance: Evidence from China's transition economy. Strategic Management Journal, 28(8), 791-804.

Li, J. J., Zhou, K. Z., \& Shao, A. T. (2009). Competitive position, managerial ties, and profitability of foreign firms in China: An interactive perspective. Journal of International Business Studies, 40(2), $339-352$.

Lohmöller, J.-B. (1989). Latent variable path modeling with partial least squares. Heidelberg: Springer.

Luo, Y. (2007). From foreign investors to strategic insiders: Shifting parameters, prescriptions and paradigms for MNCs in China. Journal of World Business, 42(1), 14-34.

Luo, Y., Huang, Y., \& Wang, S. L. (2015). Guanxi and organizational performance: A meta-analysis. Management and Organization Review, 8(1), 139-172.

Mack, O., Khare, A., Krämer, A., \& Burgartz, T. (2016). Managing in a vuca world. Cham: Springer.

Maxton, G. P., \& Wormald, J. (2014). Time for a model change: Re-engineering the global automotive industry. Cambridge: Cambridge University Press.

Mellahi, K., Frynas, J. G., Sun, P., \& Siegel, D. (2016). A review of the nonmarket strategy literature: Toward a multi-theoretical integration. Journal of Management, 42(1), 143-173.

Miller, K. D. (1993). Industry and country effects on managers' perceptions of environmental uncertainties. Journal of International Business Studies, 24(4), 693-714.

Mullen, M. R. (1995). Diagnosing measurement equivalence in cross-national research. Journal of International Business Studies, 26(3), 573-596.

Nan, Z., Liang qiao, Z., Lei Hai, M., \& Xiao, W. (2016). Do local party committees have influence over firms innovations in China? Academy of Management Annual Meeting Proceedings. https://doi. org/10.5465/AMBPP.2016.17893abstract.

Nunnally, J. C., \& Bernstein, I. H. (1994). Psychometric theory (3rd ed.). New York: McGraw-Hill.

OECD. (2007). China-Synthesis report. OECD Review of Innovation Policy. Paris: OECD.

Oke, A., Walumba, F. O., \& Myers, A. (2012). Innovation strategy, human resource policy, and firms' revenue growth. Decision Sciences, 43(2), 273-302.

Pavlou, P. A., Liang, H., \& Xue, Y. (2007). Understanding and mitigating uncertainty in online exchange relationships: A principal-agent perspective. MIS Quarterly, 31(1), 105-136.

Peng, D. X., \& Lai, F. (2012). Using partial least squares in operations management research: A practical guideline and summary of past research. Journal of Operations Management, 30(6), 467-480.

Peng, M. W., \& Luo, Y. (2000). Managerial ties and firm performance in a transition economy: The nature of a micro-macro link. The Academy of Management Journal, 43(3), 486-501.

Peng, M. W., Wang, D. Y. L., \& Jiang, Y. (2008). An institution-based view of international business strategy: A focus on emerging economies. Journal of International Business Studies, 39(5), 920-936.

Podsakoff, P. M., MacKenzie, S. B., Jeong-Yeon, L., \& Podsakoff, N. P. (2003). Common method biases in behavioral research: A critical review of the literature and recommended remedies. Journal of Applied Psychology, 88(5), 879-903.

Podsakoff, P. M., \& Organ, D. W. (1986). Self-reports in organizational research: Problems and prospects. Journal of Management, 12(4), 531-544.

Puck, J. F., Holtbrügge, D., \& Mohr, A. T. (2009). Beyond entry mode choice: Explaining the conversion of joint ventures into wholly owned subsidiaries in the peoples republic of China. Journal of International Business Studies, 40(3), 388-404.

Redding, G., \& Witt, M. (2009). China's business system and its future trajectory. Asia Pacific Journal of Management, 26(3), 381-399. 
Reinartz, W., Haenlein, M., \& Henseler, J. (2009). An empirical comparison of the efficacy of covariancebased and variance-based SEM. International Journal of Research in Marketing, 26(4), 332-344.

Revelle, W. (1979). Hierarchical cluster analysis and the internal structure of tests. Multivariate Behavioral Research, 14(1), 57-74.

Richter, N. F., Sinkovics, R. R., Ringle, C. M., \& Schlägel, C. (2016). A critical look at the use of SEM in international business research. International Marketing Review, 33(3), 376-404.

Ridge, J. W., Ingram, A., \& Hill, A. D. (2017). Beyond lobbying expenditures: How lobbying breadth and political connectedness affect firm outcomes. Academy of Management Journal, 60(3), 1138-1163.

Rindfleisch, A., \& Heide, J. B. (1997). Transaction cost analysis: Past, present, and future applications. Journal of Marketing, 61(4), 30-54.

Ringle, C. M., Sarstedt, M., \& Straub, D. (2012). Editor's comments: A critical look at the use of PLS-SEM in MIS quarterly. MIS Quarterly, 36(1), iii-xiv.

Ringle, C. M., Wende, S., \& Becker, J.-M. (2015). Smartpls 3. Boenningstedt: SmartPLS GmbH.

Rivera-Santos, M., Dussauge, P., \& Mitchell, W. (2012). Can new ventures control learning and leakage in alliances? The partial tradeoff between knowledge acquisition and protection in partnerships formed by newly created businesses. Babson Park: Babson College.

Sheng, S., Zhou, K. Z., \& Li, J. J. (2011). The effects of business and political ties on firm performance: Evidence from China. Journal of Marketing, 75(1), 1-15.

Shi, W., Markóczy, L., \& Stan, C. V. (2014). The continuing importance of political ties in China. The Academy of Management Perspectives, 28(1), 57-75.

Sojli, E., \& Tham, W. W. (2017). Foreign political connections. Journal of International Business Studies, 48(2), 244-266.

Subramani, M. R., \& Venkatraman, N. (2003). Safeguarding investments in asymmetric interorganizational relationships: Theory and evidence. Academy of Management Journal, 46(1), 46-62.

Sun, P., Mellahi, K., \& Thun, E. (2010). The dynamic value of MNE political embeddedness: The case of the Chinese automobile industry. Journal of International Business Studies, 41(7), 1161-1182.

Sun, P., Mellahi, K., \& Wright, M. (2012). The contingent value of corporate political ties. The Academy of Management Perspectives, 26(3), 68-82.

Veldhoen, S., Peng, B., \& Mansson, A. (2014). 2014 China innovation survey: China's innovation is going global. Beijing: PWC.

Voinea, C. L., \& Kranenburg, H. L. (2017). Non-market strategic management. London: Routledge.

Wanasika, I., \& Adler, T. (2011). Deception as strategy: Context and dynamics. Journal of Managerial Issues, 23(3), 364-378.

Wang, C. (2016). The subtle logics of knowledge conflicts in China's foreign enterprises. New York: Springer.

Wang, Q., Bradford, K., Xu, J., \& Weitz, B. (2008). Creativity in buyer-seller relationships: The role of governance. International Journal of Research in Marketing, 25(2), 109-118.

Wang, L., Sheng, S., Wu, S., \& Zhou, K. Z. (2017). Government role, governance mechanisms, and foreign partner opportunism in IJVs. Journal of Business Research, 76, 98-107.

Werner, S., Brouthers, L. E., \& Brouthers, K. D. (1996). International risk and perceived environmental uncertainty: The dimensionality and internal consistency of miller's measure. Journal of International Business Studies, 27(3), 571-587.

Werts, C. E., Linn, R. L., \& Jöreskog, K. G. (1974). Intraclass reliability estimates: Testing structural assumptions. Educational and Psychological Measurement, 34(1), 25-33.

Williamson, O. E. (1975). Markets and hierarchies. New York: Free Press.

Williamson, O. E. (1979). Transaction-cost economics: The governance of contractual relations. Journal of Law and Economics, 22(2), 233-261.

Williamson, O. E. (1996). The mechanisms of governance. New York: Oxford University Press.

Witt, M. (2010). China: What variety of capitalism? INSEAD Working Paper, 2010/88/EPS. https://doi. org/10.2139/ssrn.1695940.

Wold, H. (1980). Model construction and evaluation when theoretical knowledge is scarce. In J. Kmenta \& J. B. Ramsey (Eds.), Evaluation of econometric models (pp. 47-74). New York: Academic Press.

Wright, R. T., Campbell, D. E., Thatcher, J. B., \& Roberts, N. (2012). Operationalizing multidimensional constructs in structural equation modeling: Recommendations for is research. Communications of the Association for Information Systems, 30(1), 367-412. 
Wu, J. (2011). Asymmetric roles of business ties and political ties in product innovation. Journal of Business Research, 64(11), 1151-1156.

Xin, L., Meng, X., \& Chunyan, J. (2016). The role of political ties and business ties in the whole process of exploratory innovation. Academy of Management Annual Meeting Proceedings. https://doi. org/10.5465/AMBPP.2016.16936abstract.

Zaheer, A., \& Venkatraman, N. (1995). Relational governance as an interorganizational strategy: An empirical test of the role of trust in economic exchange. Strategic Management Journal, 16(5), 373-393.

Zhang, C., Cavusgil, S. T., \& Roath, A. S. (2003). Manufacturer governance of foreign distributor relationships: Do relational norms enhance competitiveness in the export market? Journal of International Business Studies, 34(6), 550-566.

Zhang, J. A., \& Cui, X. (2017). In search of the effects of business and political ties on innovation ambidexterity. International Journal of Innovation Management, 21(2), 1-27.

Zhang, Y., \& Li, H. (2010). Innovation search of new ventures in a technology cluster: The role of ties with service intermediaries. Strategic Management Journal, 31(1), 88-109.

Zhang, N., Liang, Q.-Z., Lei, H., \& Wang, X. (2016a). Are political ties only based on interpersonal relations?: The organizational political tie and its role in firms' innovations in China. Chinese Management Studies, 10(3), 417-434. https://doi.org/10.1108/CMS-01-2016-0027.

Zhang, J., \& Lin, S. (2014). Business and government. In Z.-X. Zhang \& J. Zhang (Eds.), Understanding Chinese firms from multiple perspectives (pp. 51-79). Heidelberg: Springer.

Zhang, J., Tan, J., \& Wong, P. K. (2014). When does investment in political ties improve firm performance? The contingent effect of innovation activities. Asia Pacific Journal of Management, 32(2), 363-387.

Zhang, S., Wang, Z., Zhao, X., \& Zhang, M. (2017). Effects of institutional support on innovation and performance: Roles of dysfunctional competition. Industrial Management and Data Systems, $117(1), 50-67$.

Zhang, Z.-X., \& Zhang, J. (2014). Understanding Chinese firms from multiple perspectives. Heidelberg: Springer.

Zhang, Y., Zhao, W., \& Ge, J. (2016b). Institutional duality and political strategies of foreigninvested firms in an emerging economy. Journal of World Business, 51(3), 451-462. https://doi. org/10.1016/j.jwb.2015.12.004.

Zhao, Z. J., \& Anand, J. (2009). A multilevel perspective on knowledge transfer: Evidence from the Chinese automotive industry. Strategic Management Journal, 30(9), 959-983.

Zhao, Z. J., Anand, J., \& Mitchell, W. (2005). A dual networks perspective on inter-organizational transfer of R\&D capabilities: International joint ventures in the Chinese automotive industry. Journal of Management Studies, 42(1), 127-160.

Zhou, K. Z., \& Dean, X. (2012). How foreign firms curtail local supplier opportunism in China: Detailed contracts, centralized control, and relational governance. Journal of International Business Studies, 43(7), 677-692.

Zhou, K. Z., Gao, G. Y., \& Zhao, H. (2016). State ownership and firm innovation in China. Administrative Science Quarterly, 62(2), 375-404.

Zhou, K. Z., \& Li, C. B. (2010). How strategic orientations influence the building of dynamic capability in emerging economies. Journal of Business Research, 63(3), 224-231.

Zhou, K. Z., \& Poppo, L. (2010). Exchange hazards, relational reliability, and contracts in China: The contingent role of legal enforceability. Journal of International Business Studies, 41(5), 861-881.

Zhou, W., Velamuri, V. K., \& Dauth, T. (2017). Changing innovation roles of foreign subsidiaries from the manufacturing industry in China. International Journal of Innovation Management, 21(1), 1-32. 